\title{
Which support from the French Foundation of rare disease towards clinical trial set up in rare diseases?
}

\author{
Luigi Ravagnan \\ From 1st French-Italian meeting on laminopathies and other nuclear envelope-related diseases \\ Marseille, France. 15-16 January 2015
}

The French Foundation for rare diseases (Fondation maladies rares) is a new private non-profit organisation started in 2012 by Pr. Nicolas Lévy and Céline Hubert, which pooled together their complementary experiences in the field of rare diseases, from academia and the pharmaceutical industry respectively. Headquartered in Paris at the heart of the 'Rare Diseases Platform', the Foundation reaches out to the whole national territory with its network of regional delegates. The team is now composed of 14 dedicated professionals.

The Foundation was foreseen in the $2^{\text {nd }}$ French National Rare Diseases Plan, as the flagship measure of the research axis. It was created and financially supported by 5 founders representing the patients, the research sector and the medical sector (AFM-Téléthon, Alliance Maladies Rares, National Institute of Health and Medical Research - Inserm, Conference of University Presidents - CPU and Conference of University Hospitals Directors-General).

The Foundation carries out a mission of general interest: it aims at accelerating rare diseases research programs by improving the coordination among rare diseases players, contributing to the understanding of rare diseases, the development of new treatments and the improvement of patient's care and lives.

Since its creation, 168 research projects were funded, for an amount granted in excess of $€ 4 \mathrm{M}$, and over 100 'proofs of concepts' detected, half of which actively followed to help fill the gaps towards clinical development (e.g. strengthening of the proof of concept, orphan drug designation, agreement with a private partner, European funding, etc.).

Published: 11 November 2015

\footnotetext{
Correspondence: contact@fondation-maladiesrares.com
} French Foundation for rare diseases, Paris, France
doi:10.1186/1750-1172-10-S2-033

Cite this article as: Ravagnan: Which support from the French

Foundation of rare disease towards clinical trial set up in rare diseases?

Orphanet Journal of Rare Diseases 2015 10(Suppl 2):O33.
Submit your next manuscript to BioMed Central and take full advantage of:

- Convenient online submission

- Thorough peer review

- No space constraints or color figure charges

- Immediate publication on acceptance

- Inclusion in PubMed, CAS, Scopus and Google Scholar

- Research which is freely available for redistribution
() Biomed Central
C Biomed Central

C 2015 Ravagnan This is an Open Access article distributed under the terms of the Creative Commons Attribution License (http:// creativecommons.org/licenses/by/4.0), which permits unrestricted use, distribution, and reproduction in any medium, provided the original work is properly cited. The Creative Commons Public Domain Dedication waiver (http://creativecommons.org/publicdomain/ zero/1.0/) applies to the data made available in this article, unless otherwise stated. 